\title{
The Phenological Stages of Apple Tree in the North Eastern of Iran
}

\author{
Mokhtar Karami, Mehdi Asadi* \\ Department of Geography, Hakim Sabzevari University, Sabzevar, Iran \\ Email: *Asadimehdi11@yahoo.com
}

How to cite this paper: Karami, M. and Asadi, M. (2017) The Phenological Stages of Apple Tree in the North Eastern of Iran. Computational Water, Energy, and Environmental Engineering, 6, 269-280. https://doi.org/10.4236/cweee.2017.63018

Received: September 28, 2016

Accepted: July 18, 2017

Published: July 21, 2017

Copyright @ 2017 by authors and Scientific Research Publishing Inc. This work is licensed under the Creative Commons Attribution International License (CC BY 4.0).

http://creativecommons.org/licenses/by/4.0/

(c) (i) Open Access

\begin{abstract}
The main objective of this study was to evaluate the process of parameters such as mean temperature; total precipitation on phenology and phenological stages of apple golden type in Razavi Khorasan. For this reason, long-term data of absolute minimum daily temperature, precipitation, humidity, as well as Digital Elevation Model (DEM) was used. After collecting data on phenology and Growing Degree Days (GDD) for golden apple, to pass each phenological stage at different growth stages, the start and end dates, phenological stages of the locations were identified. Then, regression equations with variable longitude, latitude and altitude on SPSS software at level of 50\% and 95\%, respectively were used, and finally phenological stages and spatial distribution maps of temperature and precipitation variables based on these equations were drawn in ARC GIS software. The analysis of the phenological stages showed that Torbate Heydarieh station has a decreasing trend which is significant at $1 \%$ in all stages of phenology and Ghoochan station does not show any significant increase or decrease trend at all stages of phenology.
\end{abstract}

\section{Keywords}

Phenological Stages, GDD, Hierarchical Analysis, Trend Analysis

\section{Introduction}

Identifying any environment and efficient use of that needs studies in different fields. In environmental studies, in order to access to a confident model, the subject of systematic approach should be pursued. The possible environmental powers are not distributed equally in all places and each country has different capabilities due to weather conditions for farming and other activities [1]. Efficiency of agricultural production largely is associated with climatic conditions. Today, the biggest problem in agricultural meteorology, the effect of climatic 
factors on products and the plants growth completely depends on the factors that create an environment [2]. Apple is one of the fruits that mankind has known and used from the prehistoric time and the start of cultivation. Apple is from the family of Rosacea and malus genus and has different varieties [3]. Cultivating the apple for the first time was done in Iran, Greece, and Rome. Now Iran has 1.40 of the total production of the world and 1.11 of the production in Asia, and the provinces of West Azerbaijan, Khorasan and Tehran have had the highest area under cultivation [4]. Apples are among the pome fruit in fruit classification. Apple trees tolerate the high temperature range of TPU and only in areas with winter temperatures reaching $-40^{\circ} \mathrm{C}$ or regions due to the warm air, cold air needed to break down the winter dormancy (1000 to 1600 hours below $7^{\circ} \mathrm{C}$ ), which is not provided, in such regions, the cultivations are not cost-effective. The proper temperature for germination in the field is about 18 to 22 degrees Celsius. Apple is harvested in an average of about 155 to 160 days after flowering conducted in fruit. Harvest season is different depending on the variety cultivated. The maximum fruiting and fruitfulness usually occur between the ages of 10 to 20 years old, and after leaving will decline gradually. Apple tree phenological development process consists of several stages that each stage is followed by next stage [5]. On one hand, the limited resources, increasing population and consequently the country require increasing food demands first, to understand existing resources correctly and, secondly, to make best use of our limited resources. Climate change is one of these natural endowments that almost are unchangeable and so success in agriculture requires the selection and planting of species which have the highest correlation to local weather conditions [5]. The first investigation regarding to agricultural climatology in Iran was carried out by Iranian Meteorological Organization in collaboration with Quanta Company in 1975 [5]; this was as a major research plan which conducted on 15 important field products. Ehtemam [6] modified apple trees and had studied the effect of climate. Taghi Bakhshi has studied the effect of climate in raising and producing apple in Damavand. The main objective of this study is to investigate the effect of parameters of mean temperature, the total precipitations in process of phenology of apple golden type in Razavi Khorasan Province.

\section{Material and Methods}

\subsection{The Studied Area}

The studied area is about $146,954 \mathrm{Km}^{2}$ consist of Razavi Khorasan, Northern Khorasan, is located in the geographical range, between the latitude of $30^{\circ} \mathrm{N}$ to $38^{\circ} \mathrm{N}$ and longitude of $55^{\circ} \mathrm{E}$ to $61^{\circ} \mathrm{E}$ from Greenwich Meridian (Figure 1).

In this study for feasibility of apples daily average minimum and maximum temperatures of 12 synoptic stations has been used during the period of 25 years including: Mashhad, Sabzevar, Ghoochan, Golmakan, Neyshaboor, Sarakhs, Gonabad, Kashmar, Torbate jam, Torbate Heydarieh, Ferdous and Boshrooyeh. The absolute minimum daily temperature, precipitation, humidity, as well as Digital Elevation Model (DEM) were used to identify areas favorable and unfa- 


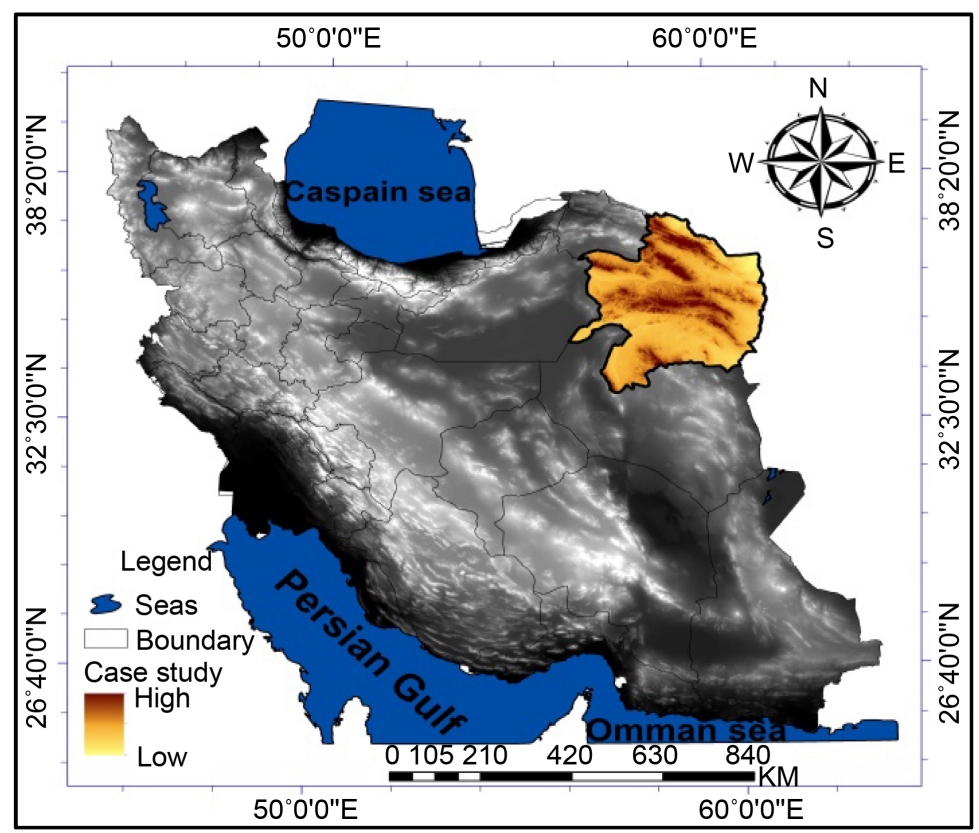

Figure 1. Location of the study area in the country.

vorable for apple cultivation. Since the base temperature that apple trees can tolerate is between -30 to 35 degrees Celsius, all areas of the province are considered favorable for apple cultivation. Each plant needs a certain number of heat units for germination, growth, stem elongation, maturity. This is called constant thermal units that defers from one plant to another. One of the most important issues in Climatology is checking the Degree Days (DD). Most physiological changes such as the growth of plants and hydrologic phenomena such as snow melting are function under the environmental thermal power. For this purpose, the heat index is used as an indicator of Growing Degree Days (GDD). Each process is activated at a certain temperature threshold, i.e. the threshold for melting snow is zero degrees Celsius and the threshold for apples growth is 7 degrees Celsius. So to estimate the degree-days for different periods of cultivation is one of the essential tasks. Since the beginning of active growth apple time begins the daily average temperature of 7 degrees Celsius exceeds the threshold value, so in this study to calculate the GDD, The base temperature of $7^{\circ} \mathrm{C}$ was included. GDD calculation formula is as follows:

$$
\mathrm{GDD}=\sum_{a}^{b}\left\{\left[\frac{T_{\max }+T_{\min }}{2}\right]-T_{b}\right\}
$$

where, GDD is Growing Degree Days $T_{\max } T_{\min }$ are the maximum and minimum daily temperatures. $T_{b}$ the base temperature is 7 degrees centigrade, $a$ and $b$ are the start and finish the phenology process [7].

\subsection{Mann Kendall Test}

Presence or absence of trend, time series analysis and proposed climate change are divided in two categories: parametric and nonparametric methods. Parametric methods are mainly based on the regression equation on time series data. 
Nonparametric methods of application compared to parametric methods are extensive and impressive. For a series that is not fitted on them and skewed distribution of specialty or high elongation using non-parametric methods are more appropriate. One of the most widely used non-parametric is Mann-Kendall test methods are used for time series trend analysis [8]. This conventional technique widely used in the analysis process Hydrological and Meteorological Series. The strengths of this approach may be appropriate to use it to locate the statistical distribution of certain series which do not follow-up the point. Minimal influences of this method of limit values that are seen in some time series are as well as other advantages of this approach [9] [10] [11] [12]. The null hypothesis of this test implies randomness and lack of trends in data series. Assuming acceptance of a (reject the null hypothesis) is evidence of trends in data series. This test is calculated in two ways. 1) Test of statistic (T) Mann-Kendall. 2) Test of chart Mann-Kendall.

The calculation of the difference between each observation with each other and function symbols and parameter extraction the $s$ parameter actions as follows:

$$
s=\sum_{i=2}^{n} \sum_{j=1}^{i-1} \operatorname{sign}\left(x_{i}-x_{j}\right)
$$

where $n$ is the number of observation, and $x_{i} \& x_{j}$ respectively are the $j$-th and $i$-th members of the series, the sign function is calculate as follows:

$$
\operatorname{sgn}(x)= \begin{cases}1 & \text { if } x_{i}-x_{j}>0 \\ 0 & \text { if } x_{i}-x_{j}=0 \\ -1 & \text { if } x_{i}-x_{j}<0\end{cases}
$$

For independent random variables with uniform distribution and without group (Two or more data with the same numerical values in the series are ordered to follow). The mean and variance(s) are as follows:

$$
\begin{gathered}
\operatorname{var}(\mathrm{s})=\frac{n(n-1)(2 n+5)}{18}, \quad n \geq 10 \\
\mathrm{E}(\mathrm{s})=0
\end{gathered}
$$

where $n$ is the number of observations data, if there is duplicate data observations, the variance are calculated as follows:

$$
\operatorname{var}(s)=\frac{1}{18}\left[n(n-1)(2 n+5)-\sum_{p=1}^{q} t_{p}\left(t_{p}-1\right)\left(2 t_{p}+5\right)\right], n<10
$$

So that $q$ is the number of repeated groups. For example, if in a given series, only two values are equal we will have a nut with the resistant of $2\left(t_{p-1}\right)$.

If a data series is more than ten, $s$ will follow a normal distribution and standard statistical criteria $(z)$ will be as follows:

$$
Z= \begin{cases}\frac{s-1}{\sqrt{\operatorname{var}(s)}} & \text { if } s>0 \\ \frac{s+1}{\sqrt{\operatorname{var}(s)}} & \text { if } s=0\end{cases}
$$


This test is a two-way, if $|Z| \leq z_{a / 2}$ then the null hypothesis is accepted this means that in the action produced by Mann Kendall the numbers with the positive sign have the increasing trend and the numbers with the negative symbol indicate the lack of trend. This should be noted that numbers between \pm 1.96 are not significant. But the numbers out of \pm 1.96 and \pm 2.58 respectively are significant at 95 and 99 percent. Due to lack of monitoring data from phenological stages of apple in the agricultural weather stations on the base of $\mathrm{BBCH}$ scale, Golden apple monitoring data has been used as representative of apple family. This information is measured at the agriculture weather station of Golmakan. This is based on the main stages of BBCH scale (Table 1). As can be seen phenological stages are; first stage (bud formation), the second stage (bud break), the third stage (flowering), the fourth stage (the fruit) and the fifth stage (ripening).

After collecting data on phenology and growing degree days required passing each phenological stage of Golden apple variety at different growth stages, start and ending dates of phenological stages of the stations were identified. Then, regression equations with variables of longitude, latitude and altitude with the probability of $95 \%$ were calculated in SPSS software, and finally the map of spatial distribution at different stages based on these equations were drawn in Arc GIS software and spatial distribution of the mean temperature and total precipitation maps were drawn. Analysis of the phenological stages, mean temperature and total precipitation were evaluated by Mann-Kendall test in Table 1.

\section{Results and Discussion}

Given that one of the major limiting factors for raising the apple is not meeting the required GDD in a few cases from the stations, the needed growing degree days were used to identify the areas that were suitable and unsuitable for apple cultivation,. Therefore, after determining the required growing degree days for the period of 25 years in 12 synoptic stations in the study area, linear regression method based on digital elevation model (DEM) was used to generalize the results to a wide study area. The relationship between GDD with altitude, latitude is shown in Equation (7):

$$
\mathrm{Y}=-4802.071-6.349 \text { long }-43.699 \mathrm{lat}-0.093 \mathrm{E}
$$

In the above equation $\mathrm{Y}$ represents a growing degree days, lat represents the

Table 1. Phenological stages and climatic needs of apple.

\begin{tabular}{cccc}
\hline $\begin{array}{c}\text { The name of } \\
\text { phenological } \\
\text { process }\end{array}$ & Description & $\begin{array}{c}\text { The required } \\
\text { heat units } \\
\text { (degree days) }\end{array}$ & $\begin{array}{c}\text { The cumulative thermal units } \\
\text { (degree days) }\end{array}$ \\
\hline First & Bud formation & 32.4 & 32.4 \\
Second & Bud break & 80.4 & 112.8 \\
Third & Flowering & 73.2 & 186 \\
Fourth & Growing fruit & 1977 & 2163 \\
Fifth & Fruit ripening & 623 & 2786 \\
\hline
\end{tabular}


latitude, long reagents the longitude and $\mathrm{E}$ represents the altitude. Coefficients of determination and correlation equation respectively are 77 and 61 percent. Figure 2, the map is showing the amount of growing degree days at the level of 50 percent. As it indicates, in the northern part of the study area, such as Golmakan and Ghoochan, GDD requirements are not met (2535 to 2658) and the regions are considered as quite poor ones. Western and central and eastern areas such as Kashmar, Sabzevar, Sarakhs and Torbate Heydarieh component areas are considered as quite favorable in terms of supply of growing degree days. Figure 3,

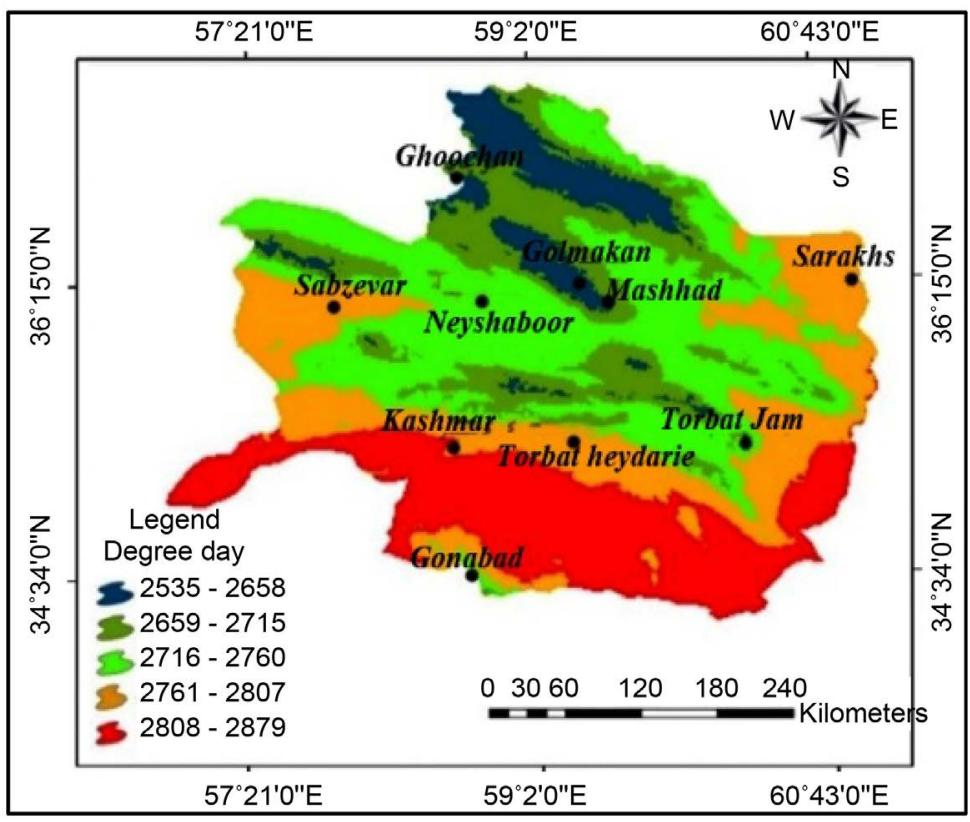

Figure 2 . The map of growing degree days at $50 \%$ probability.

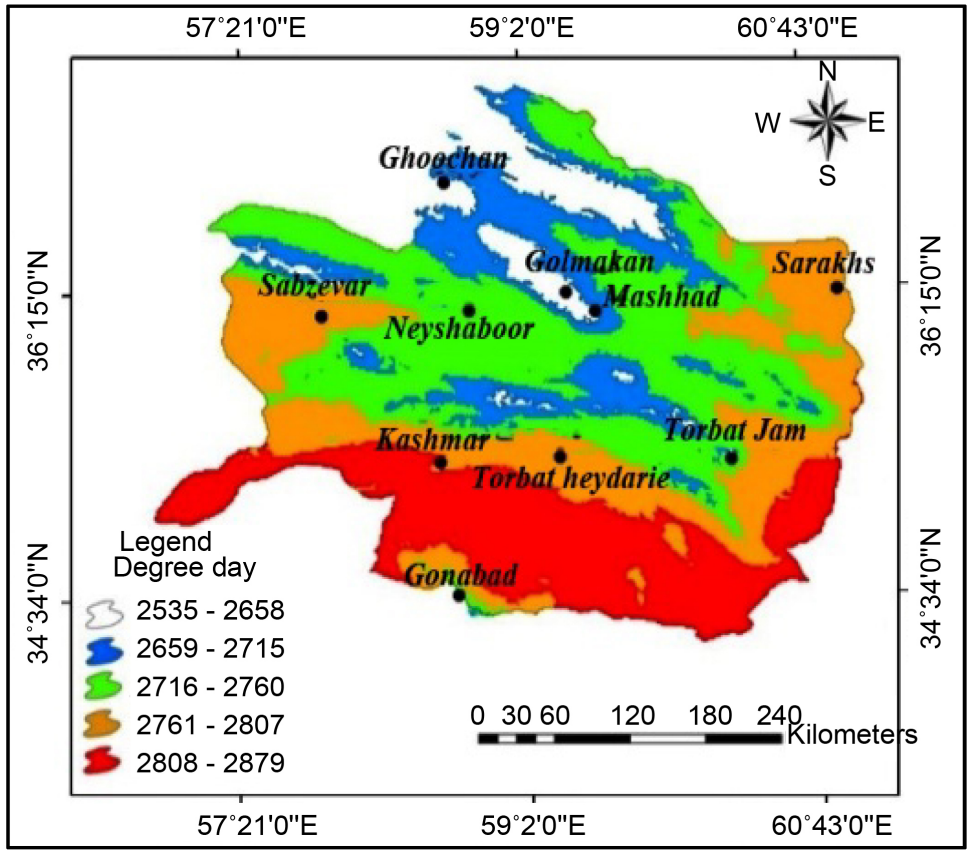

Figure 3. The map of planted area with $50 \%$ probability. 
Shows the cultivation areas in regardless of stations that are not covered by required growing degree days. The relationship between the starting date of phenological stages with latitude, longitude and altitude at $95 \%$ is shown in Table 2.

Figures 4-8 maps indicate the start date of phenological stages at the level of 95 percent. According to Figure 4, the first stage (bud formation) in the southwestern and western of the studied area (Kashmar, Sabzevar) begins earlier and in Torbate jam begins later. The phenology spatial distribution of the second stage (bud break) is shown in Figure 5. The date of beginning of this process in the Southwestern and Western regions of the studied area (parts of Kashmar, Sabzevar) takes place from 22 March to 10 April and at the central and nor-

Table 2. The relationship between phonological stages with latitude, longitude and altitude at the level of $95 \%$.

\begin{tabular}{|c|c|c|c|}
\hline $\begin{array}{l}\text { The process of } \\
\text { phenology }\end{array}$ & $\begin{array}{l}\text { Relations between phenological stages } \\
\text { with latitude, longitude, and altitude }\end{array}$ & $\begin{array}{c}\text { The } \\
\text { coefficient of } \\
\text { determination }\end{array}$ & $\begin{array}{c}\text { The } \\
\text { coefficient } \\
\text { of } \\
\text { correlation }\end{array}$ \\
\hline $\begin{array}{l}\text { The first stage, } \\
\text { bud formation }\end{array}$ & $\mathrm{Y}=-339.172+3.780$ long + 5.323lat $+0.021 \mathrm{E}$ & 79 & 89 \\
\hline $\begin{array}{l}\text { The second phase, } \\
\text { bud break }\end{array}$ & $\mathrm{Y}=-387.248+4.494 \mathrm{long}+5.771 \mathrm{lat}+0.024 \mathrm{E}$ & 89 & 94 \\
\hline $\begin{array}{l}\text { The third stage, } \\
\text { flowering }\end{array}$ & $\mathrm{Y}=-425.621+4.822 \mathrm{long}+6.434 \mathrm{lat}+0.028 \mathrm{E}$ & 87 & 93 \\
\hline $\begin{array}{l}\text { The fourth stage, } \\
\text { fruit growth }\end{array}$ & $\mathrm{Y}=-1128.199+11.237$ long + 17.569lat $+0.071 \mathrm{E}$ & 89 & 94 \\
\hline $\begin{array}{l}\text { The fifth stage, } \\
\text { ripening }\end{array}$ & $Y=-1632.420+17.530$ long +21.394 lat $+0.056 E$ & 84 & 92 \\
\hline
\end{tabular}

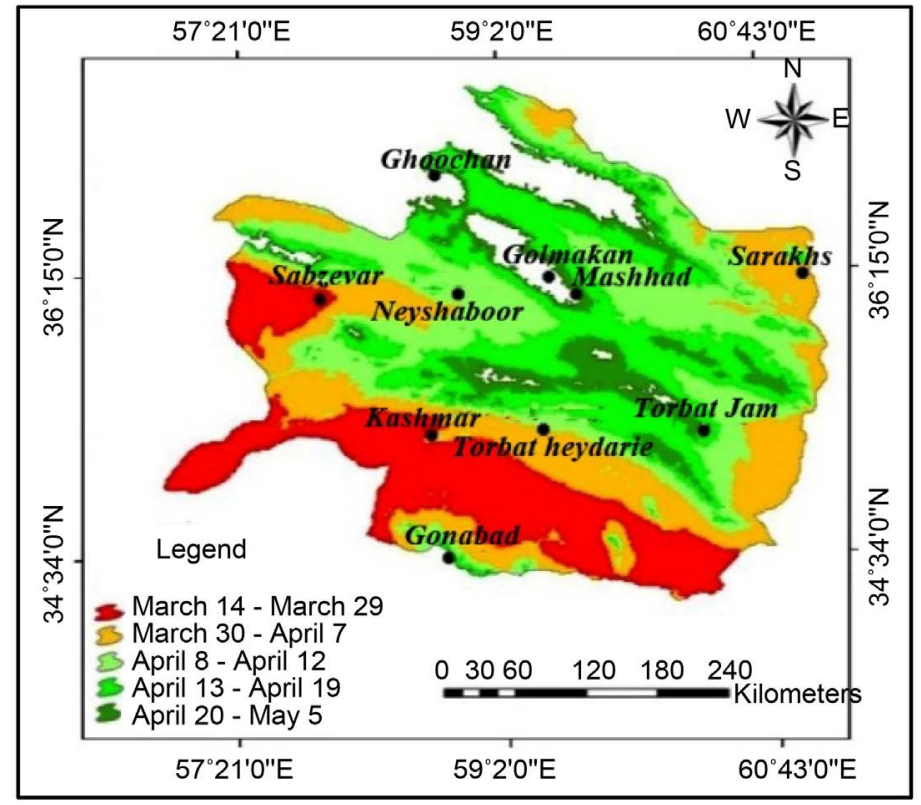

Figure 4. The date of commencement of the first stage of phenology with $95 \%$. 


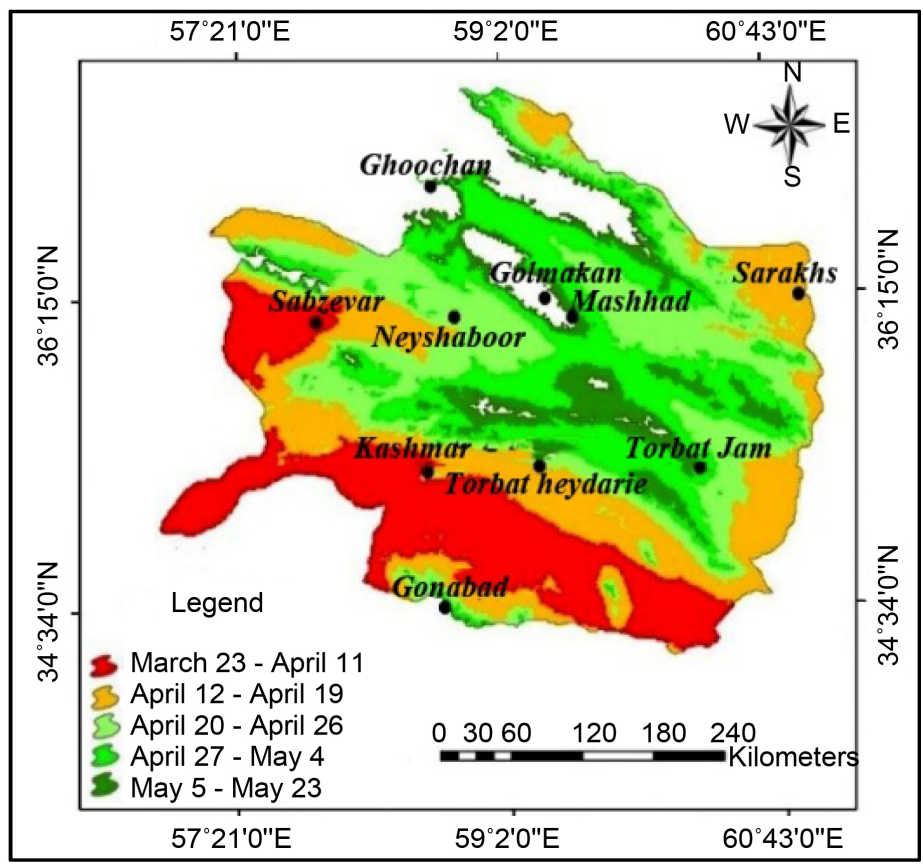

Figure 5. The date of commencement of the second stage of phenology at $95 \%$.

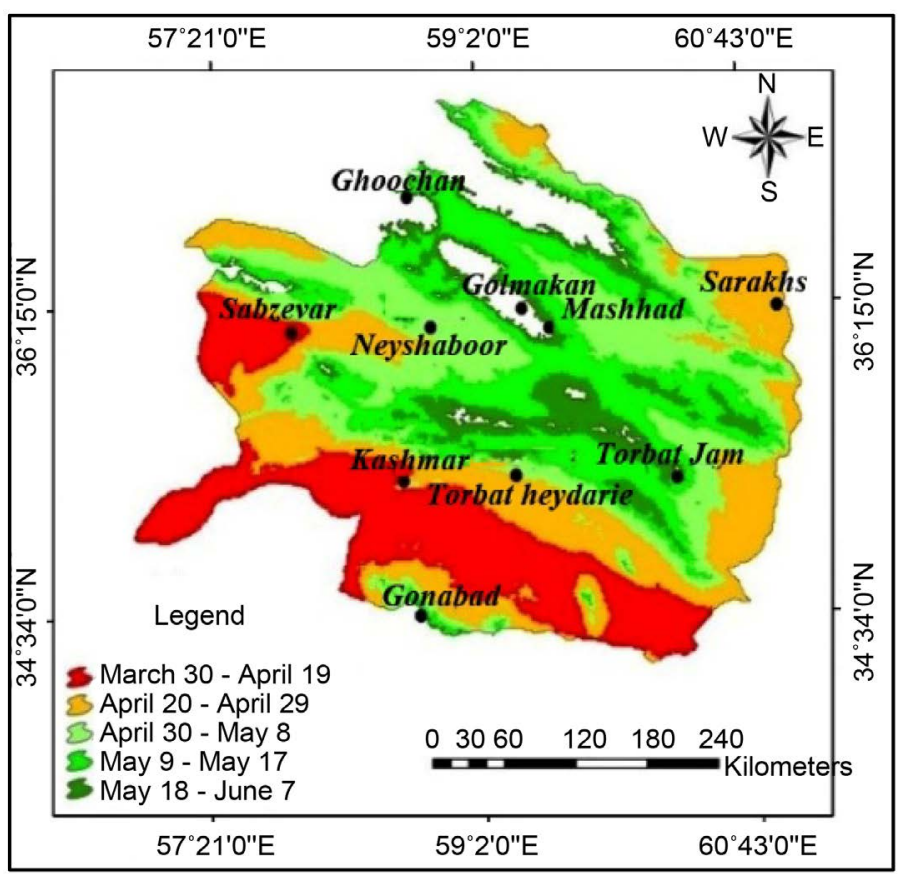

Figure 6. The date of third step of phenology with $95 \%$.

theastern regions occurs in 4 May to 22 May. Figure 6 shows the spatial distribution of the third stage of phenology (flowering). This stage in the southern of Kashmar, and Sabzevar and parts of the South Eastern region starts from 29 March to 18 April. In the central and northern areas such as Mashhad, Torbate jam, north of Torbate Heydarieh and Gonabad starts from 7 May to 16 May. Figure 7 shows the spatial distribution date for the start of the fourth stage of 


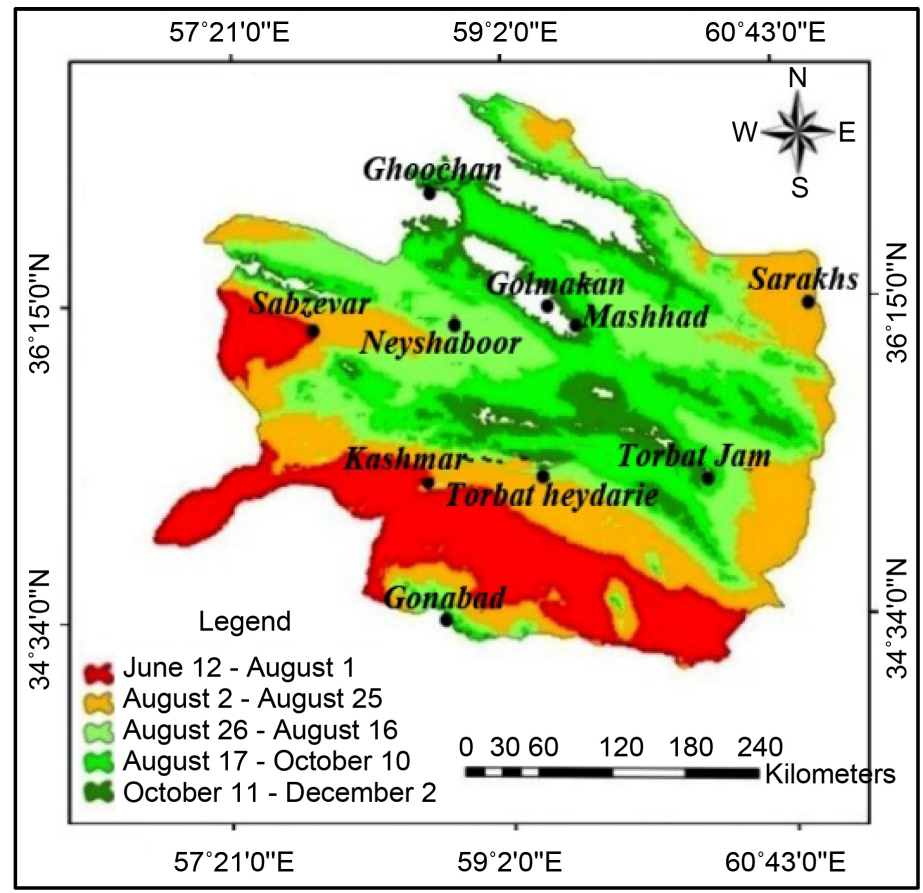

Figure 7. The date of fourth stage of phenology at $95 \%$.

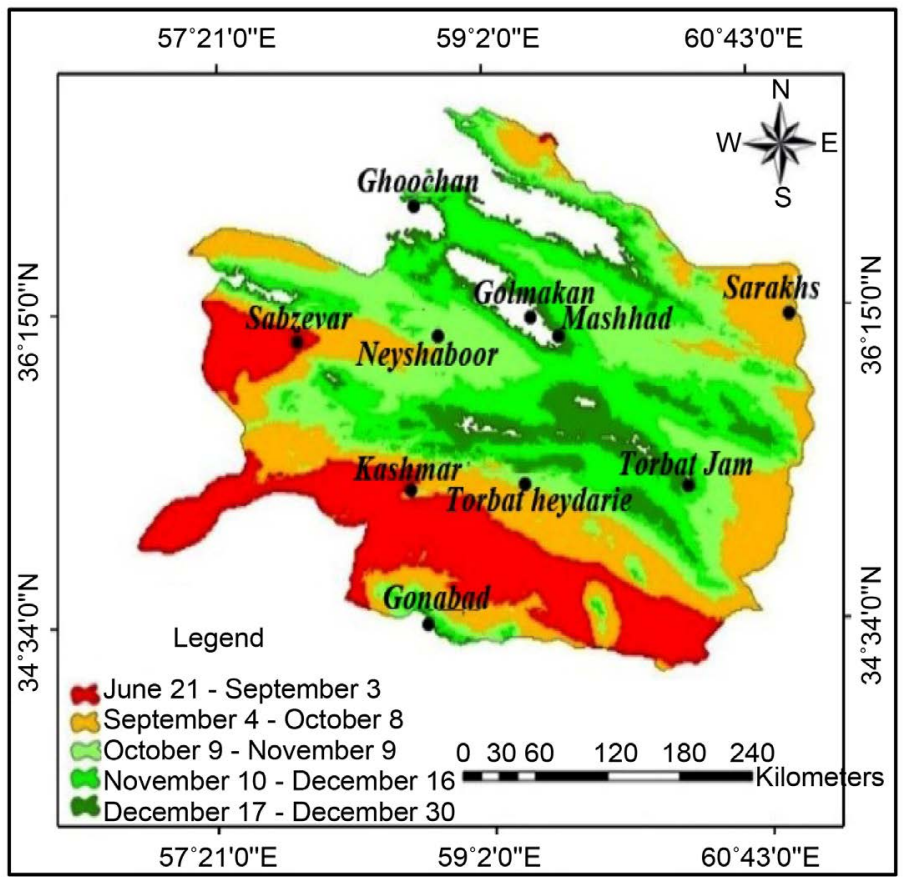

Figure 8. The date of fifth stage of plant phenology with 95\%.

phenology (the fruit growing). This stage in the West and Southeast regions (West of Sabzevar and Kashmar) starts from 12 June to $1^{\text {st }}$ of August. In the northern and central areas such as Mashhad and small sections of Torbate jam, begins from 17 September to 10 October. Figure 8 shows the spatial distribution of fifth stage of phenology (ripening). This stage in the West of Sabzevar, Kashmar and north of Gonabad begins from 21st of June to 3rd of September. In the 
northern and central areas such as Mashhad, small sections from north of Torbate Heydarieh and Torbate jam starts from $17^{\text {th }}$ of December to $30^{\text {th }}$ of December.

Table 3 shows the studies of phenological stages of apple with Mann-Kendall. As it is indicate Torbate Heydarieh at all stages of phenology has a significant decreasing trend at $1 \%$ of confidence level. Ghoochan station at all stages of phenology does not show any significant increase or decrease. The first step in Sabzevar station has the significant decrease in the level of $5 \%$ and the second phase has a decreasing trend significant at $1 \%$ of confidence level. The negative trend means that the earlier period of renewed growth over the previous year occurred sooner and has gone backward.

Table 4 shows the results of the studies of mean temperature in the relative stages of apple phenology with Mann-Kendall test. As it is shows in all stations except Sabzevar and Ghoochan, stages of fruit growth to ripening have a significantly decreasing trend at $1 \%$. The negative trend means that period of renewed growth over has occurred earlier than the previous year and has moved backwards.

Table 5 shows the results of studying Total precipitation trend in the Apple phenological stages Mann-Kendall test. As can be seen at all stations significant increasing or decreasing trend was not observed in all phenological stages. Also, as it is shows from the first to forth of phenological stages at the stations of Mashhad, Golmakan and Ghoochan indicate the maximum total precipitation and stations of Sabzevar, Kashmar and Gonabad have the lowest total rainfall respectively. In the fourth to fifth stages, the stations of Ghoochan and Golmakan have the maximum total precipitation and the stations of Gonabad, Torbate jam and Sarakhs have the lowest total precipitation.

Table 3. Study the phenological stages of apple with Mann-Kendall test.

\begin{tabular}{|c|c|c|c|c|c|c|c|c|c|c|}
\hline \multirow{2}{*}{$\begin{array}{c}\text { The process } \\
\text { of phenology } \\
\text { Station }\end{array}$} & \multicolumn{2}{|c|}{$\begin{array}{c}\text { Bud break } \\
\text { stage }\end{array}$} & \multicolumn{2}{|c|}{$\begin{array}{c}\text { Bud } \\
\text { formation } \\
\text { stage }\end{array}$} & \multicolumn{2}{|c|}{$\begin{array}{c}\text { Flowering } \\
\text { stage }\end{array}$} & \multicolumn{2}{|c|}{$\begin{array}{c}\text { Stages of } \\
\text { fruit } \\
\text { growth }\end{array}$} & \multicolumn{2}{|c|}{$\begin{array}{l}\text { Fruit } \\
\text { ripening } \\
\text { stage }\end{array}$} \\
\hline & $\mathrm{Z}$ & PV & $\mathrm{Z}$ & PV & Z & PV & $\mathrm{Z}$ & PV & $\mathrm{Z}$ & PV \\
\hline Sabzevar & 0 & -1.6 & 0.1 & -1.1 & 0.0 & -1.7 & 0 & $-2.7^{\star \star}$ & 0 & $-2.3^{\star}$ \\
\hline $\begin{array}{c}\text { Torbate } \\
\text { Heydarieh }\end{array}$ & 0 & $-3.1^{\star *}$ & 0.0 & $-2.9^{\star *}$ & 0.0 & $-2.9^{\star *}$ & 0 & $-3.6^{\star *}$ & 0 & $-3.2^{\star *}$ \\
\hline Sarakhs & 0 & $-3.4^{\star *}$ & 0.0 & $-3.1^{\star *}$ & 0.0 & $-2.3^{*}$ & 0 & $-2.6^{* *}$ & 0 & $-2.4^{*}$ \\
\hline Kashmar & 0 & $-2.9^{* *}$ & 0.0 & $-2.7^{\star \star}$ & 0.0 & $-2.6^{* *}$ & 0 & $-2.6^{\star *}$ & 0 & $-2.3^{*}$ \\
\hline Neyshabur & 0 & $-2.9^{\star *}$ & 0.0 & $-2.9^{\star *}$ & 0.0 & $-2.4^{*}$ & 0 & $-2.8^{\star *}$ & 0 & $-2.4^{\star}$ \\
\hline Mashhad & 0 & $-3.2^{* *}$ & 0.0 & $-3.1^{\star \star}$ & 0.0 & $-2.1^{\star}$ & 0 & $-2.3^{\star}$ & 0 & $-2.8^{\star *}$ \\
\hline Torbate jam & 0 & $-2.7^{\star *}$ & 0.0 & $-2.7^{\star *}$ & 0.0 & $-2.3^{\star}$ & 0 & -1.8 & 0 & -1.1 \\
\hline Golmakan & 0 & $-1.9^{\star}$ & 0.0 & $-3.2^{\star *}$ & 0.0 & $-2.4^{\star}$ & 0 & $-3^{\star *}$ & 0 & $-3^{* *}$ \\
\hline Ghoochan & 0 & -1.7 & 0.4 & -0.1 & 0.1 & -0.9 & 0 & -1.5 & 0 & -1.8 \\
\hline Gonabad & 0 & $-3.9^{\star *}$ & 0.0 & $-3.9^{\star *}$ & 0.0 & $-3.5^{\star *}$ & 0 & $-3.3^{\star *}$ & 0 & $-2^{*}$ \\
\hline
\end{tabular}


Table 4. Study the trend of mean temperature in phenological stages of apple with MannKendall.

\begin{tabular}{cccccccccc}
\hline The process of phenology & $\begin{array}{c}\text { Bloom to bud } \\
\text { formation stage }\end{array}$ & $\begin{array}{c}\text { Bud formation } \\
\text { and flowering } \\
\text { stage }\end{array}$ & $\begin{array}{c}\text { Flowering stage } \\
\text { to fruit growth }\end{array}$ & $\begin{array}{c}\text { Fruit growth } \\
\text { process to } \\
\text { ripening }\end{array}$ \\
\hline Station & $\mathrm{Z}$ & $\mathrm{PV}$ & $\mathrm{Z}$ & $\mathrm{PV}$ & $\mathrm{Z}$ & $\mathrm{PV}$ & $\mathrm{Z}$ & $\mathrm{PV}$ \\
\hline Sabzevar & 0.3 & 0.64 & -0.84 & 0.19 & -1.21 & 0.12 & 1.37 & 0.91 \\
Torbate Heydarieh & 0.5 & 0.71 & 0 & 0.5 & -0.84 & 0.19 & 1.05 & 0.85 \\
Sarakhs & 0.7 & 0.78 & -0.95 & 0.17 & -0.31 & 0.37 & $3.75^{* *}$ & 0.99 \\
Kashmar & 0.4 & 0.68 & 0.26 & 0.60 & 0.05 & 0.52 & $2.16^{*}$ & 0.98 \\
Neyshabur & 0.5 & 0.69 & -0.33 & 0.36 & 1.35 & 0.91 & $2.67^{* *}$ & 0.99 \\
Mashhad & 0.3 & 0.64 & 0 & 0.5 & 1.32 & 0.90 & $3.06^{* *}$ & 0.99 \\
Torbate jam & 0.4 & 0.68 & 0.41 & 0.66 & 0.62 & 0.73 & $2.65^{* *}$ & 0.99 \\
Golmakan & -0.9 & 0.17 & 0 & 0.5 & $2.37^{*}$ & 0.99 & $2.69^{* *}$ & 0.99 \\
Ghoochan & 0.2 & 0.58 & -0.95 & 0.17 & 1 & 0.84 & $3.01^{* *}$ & 0.99 \\
Gonabad & 0.73 & 0.77 & 1.21 & 0.88 & -0.26 & 0.39 & $2.32^{*}$ & 0.98 \\
\hline
\end{tabular}

Table 5. Shows study of the trend in total precipitation in phenological stages of apple with Mann-Kendall test.

\begin{tabular}{|c|c|c|c|c|c|c|c|c|}
\hline \multirow{2}{*}{$\begin{array}{c}\text { The process of phenology } \\
\text { Station }\end{array}$} & \multicolumn{2}{|c|}{$\begin{array}{c}\text { Bud to bud } \\
\text { formation stage }\end{array}$} & \multicolumn{2}{|c|}{$\begin{array}{l}\text { Bud formation and } \\
\text { flowering stage }\end{array}$} & \multicolumn{2}{|c|}{$\begin{array}{l}\text { Flowering } \\
\text { stage to fruit } \\
\text { growth }\end{array}$} & \multicolumn{2}{|c|}{$\begin{array}{c}\text { fruit growth } \\
\text { process to } \\
\text { ripening }\end{array}$} \\
\hline & $\mathrm{Z}$ & PV & $\mathrm{Z}$ & PV & $\mathrm{Z}$ & PV & $\mathrm{Z}$ & PV \\
\hline Sabzevar & -0.6 & 0.2 & 0.6 & 0.7 & 0.4 & 0.6 & -0.7 & 0.2 \\
\hline Torbate Heydarieh & 0.1 & 0.5 & -0.1 & 0.4 & 1.7 & 0.9 & -0.8 & 0.1 \\
\hline Sarakhs & -0.4 & 0.3 & -0.1 & 0.4 & -0.1 & 0.4 & -0.3 & 0.3 \\
\hline Kashmar & -0.6 & 0.2 & -1.0 & 0.1 & 0 & 0.4 & -0.3 & 0.3 \\
\hline Neyshabur & 0 & 0.5 & 1.8 & 0.9 & 0.0 & 0.5 & -1.2 & 0.1 \\
\hline Mashhad & -0.0 & 0.4 & -0.5 & 0.3 & 0.0 & 0.5 & 0.1 & 0.5 \\
\hline Torbate jam & -1.3 & 0.0 & 0.0 & 0.5 & 0.4 & 0.3 & -0.4 & 0.3 \\
\hline Golmakan & -0.4 & 0.3 & 0.3 & 0.6 & 0.3 & 0.6 & -1.4 & 0.0 \\
\hline Ghoochan & $-1.9^{*}$ & 0.0 & 0.4 & 0.6 & 0.0 & 0.5 & -1.9 & 0.0 \\
\hline Gonabad & -1.7 & 0.9 & $-2.2^{*}$ & 0.9 & -0.5 & 0.2 & -0.2 & 0.4 \\
\hline
\end{tabular}

\section{Conclusion}

The results of this study show that GDD in the uplands is less than the amount needed to ripen apples and therefore excluded from the scope of firm's cultivation. Studying the maps of phenological stages shows that southern and southwestern regions in terms of supply of growing degree days are very suitable for apple cultivation areas and the period of growing apples is from germination to fruit ripening period from 13 March to 3 September in these areas. But in central and northern part due to the higher altitude and lower temperatures, the phenological stage begins later than the southern regions. In combination with the results of this study, it can identify favorable areas for apples in the studied area 
and based on that, the date of cultivation and the amount of production can be progressed. The analysis of the phenological stages shows Torbate Heydarieh stations in all phenological stages have a significant decreasing trend at $1 \%$ confidence level. Ghoochan station at all stages of phenology does not show any type of significant increase or decrease. The negative trend means that earlier period of renewed growth compared to the previous year has occurred sooner and has moved backwards. In all phenological stages, stations Mashhad, Golmakan and Torbate jam have the lower mean temperature and the average temperature is higher in Sabzevar station. The mean temperature trend analysis at all stations except Sabzevar and Ghoochan at the stage of growth to ripening fruit has a decreasing trend significantly at $1 \%$. The central and northern parts have the most precipitation and the western and southern and southeastern part have the lowest precipitation.

\section{References}

[1] Parhizkar, A. and Sarmady, A. (2001) Khomeins Plain Capable of Sliding Poll Farmer. Magazine Geographical Space, Azad University of Ahar, No. 3: 40-23.

[2] Alizadeh, A. and Kouchaki, A. (1989) Agriculture and Climate. Javid Press, 140.

[3] Maniee, A. (1992) Apple and Its Cultivation. Iranian Technical Publications, $1^{\text {st }}$ Printing.

[4] Taghi Bakhshi, N. (2005) The Effect of Climate on the Production and Cultivation of Apple Tree in the City of Damavand. Tarbiat Modarres University, Tehran.

[5] Quanta (1975) Guidebook to the Needs and Limitations of Meteorology for 15 Iranian Main Products, Agricultural Meteorology.

[6] Ehtemam, M.H. and Khandan, A. (2003) Modified Apple Trees and in Horticultural Plant Breeding. Mashhad, Astan Ghods Razavi Publications.

[7] Kamali, Gh.A. and Bazgir, S. (2008) Wheat Yield Estimation Base on Agricultural Meteorology Indices in Some Areas of the Western Part of the Country. Journal of Agricultural Sciences and Natural Resources, XV, 122-113.

[8] Hejazizadeh, Z. and Parvin, N. (2010) Assessment of Changes in Temperature and Precipitation in Tehran during the Past Half Century. Geography and Regional Planning, 43-56.

[9] Chambers, F. and Ogle, M. (2002) Climate Change, Vole. 1, London, Rout1, Ledge.

[10] Chambers, F. and Ogle, M. (2002) Climate Change, Vole. 2, London, Rout, Ledge.

[11] Azizi, Gh. (2000) Estimates of Effective Rainfall in Relation to the Cultivation of Wheat (Case Study: Plain Khorramabad). Geographic Studies, No. 39, 123-115.

[12] Azizi, Gh. and Yarmohamady, D. (2003) The Relationship between Climatic Parameters and Yield of Wheat with Regression Model, Geographic Preceding Studies, 44 . 
Submit or recommend next manuscript to SCIRP and we will provide best service for you:

Accepting pre-submission inquiries through Email, Facebook, LinkedIn, Twitter, etc. A wide selection of journals (inclusive of 9 subjects, more than 200 journals)

Providing 24-hour high-quality service

User-friendly online submission system

Fair and swift peer-review system

Efficient typesetting and proofreading procedure

Display of the result of downloads and visits, as well as the number of cited articles Maximum dissemination of your research work

Submit your manuscript at: http://papersubmission.scirp.org/

Or contact cweee@scirp.org 